\title{
Oropharyngeal (p16-Negative) Cancer pN2a TNM Finding v8
}

National Cancer Institute

\section{Source}

National Cancer Institute. Oropharyngeal (p16-Negative) Cancer pN2a TNM Finding v8. NCI Thesaurus. Code C132966.

Oropharyngeal (p16-neg ative) cancer with metastasis in a single ipsilateral lymph node, 3 $\mathrm{cm}$ or smaller in greatest dimension and $\operatorname{ENE}(+)$; or a single ipsilateral lymph node larger than $3 \mathrm{~cm}$ but not larger than $6 \mathrm{~cm}$ in greatest dimension and ENE(-). (from AJCC 8th Ed.) 